\title{
A REVIEW OF COMPRESSED AIR ENGINE IN THE VEHICLE PROPULSION SYSTEM
}

\author{
Michal Korbut $^{*}$ (i) , Dariusz Szpica** \\ *Doctoral School, Bialystok University of Technology, 45A Wiejska Str., 15-351 Bialystok, Poland \\ ${ }^{*}$ Faculty of Mechanical Engineering, Bialystok University of Technology, 45C Wiejska Str., 15-351 Bialystok, Poland \\ m.korbut@doktoranci.pb.edu.pl, d.szpica@pb.edu.pl
}

received 20 August 2021, revised 6 September 2021, accepted 13 September 2021

\begin{abstract}
Engines powered by compressed air as a source of propulsion are known for many years. Nevertheless, this type of drive is not commonly used. The main reason for not using commonly is the problem with the low energy density of the compressed air. They offer a number of advantages, primarily focusing on the possibility of significantly lowering the emissions of the engine. Their emissivity mainly depends on the method of obtaining compressed air. This also has an impact on the economic aspects of the drive. Currently there are only a few, ready to implement, compressed air powered engine solutions available on the market. A major advantage is the ability to convert internal combustion engines to run with compressed air. The study provides a literature review of solutions, focusing on a multifaceted analysis of pneumatic drives. Increasing vehicle approval requirements relating to their emissions performance are encouraging for the search of alternative power sources. This creates an opportunity for the development of unpopular propulsion systems, including pneumatic engines. Analysing the works of some researchers, it is possible to notice a significant increase in the efficiency of the drive, which may contribute to its popularisation.
\end{abstract}

Key words: emission reduction, drive sources, pneumatic engine, compressed air engine, pneumatic hybrid

\section{INTRODUCTION}

As a result of a significant decrease of air quality in large cities and the fight against emissions of harmful substances, more and more restrictive and at the same time more difficult to fulfil legislative limits for exhaust emissions are introduced (Bielaczyc and Woodburn, 2019; Kamguia Simeu and Kim, 2018; Pavlovic et al., 2016; Varella et al., 2017). An additional factor contributing to the tightening of the criteria necessary for the approval of vehicles was the detection of fraud done by the automotive companies during the emissivity tests, which directly contributed to the modification of the driving tests (Puškár et al., 2019). The main changes to the approval tests are the introduction of a new exhaust emission test cycle known as Worldwide Harmonized Light Vehicles Test Procedure (WLTP) replacing the cycle New European Driving Cycle (NEDC) and the implementation of the measurement in real traffic real drive test (RDE) (Hooftman et al., 2018; Sileghem et al., 2014). The main differences between the WLTP cycle and the NEDC cycle are the increased measurement duration time, the more than doubled total distance travelled during the test and the higher average velocity (Ligterink et al., 2016). These changes, together with the complementation of laboratory tests with tests in road traffic, contribute to bringing the test results closer to the real-vehicle emissivity. Another step undertaken by the European Commission is the tightening of the limit on the average $\mathrm{CO}_{2}$ emissions imposed on vehicle manufacturers, from $2020, \mathrm{CO}_{2}$ emissions during vehicle approval can be $95 \mathrm{~g} / \mathrm{km}$, a $15 \%$ reduction by 2025 and a $37.5 \%$ reduction by 2030 (García et al., 2020). This forces automotive companies to look for new solutions for reducing the emissions of internal combustion engines (Fig. 1), including the following:
- ATAC (Active Thermo-Atmosphere Combustion) - heating of the fuel and air mixture causing more rapid combustion (Akira and Hideo, 2004; Onishi et al., 1979; Xingcai et al., 2008);

- ACT (Active Cylinder Technology) - system which deactivates the work in cylinders when driving with a constant load (Gosala et al., 2017; Joshi et al., 2017; Lee et al., 2018; Muhamad Said et al., 2014);

- SPCCI (Spark-Controlled Compression Ignition) - compressed mixture ignition controlled by a spark plug (Hannan et al., 2014; Olesky et al., 2014; Robertson and Prucka, 2019; Shuai et al., 2018);

- HCCl/CAl (Homogeneous Charge Compression Ignition/Controlled Auto-ignition) - combustion of a homogeneous mixture (Jeuland et al., 2004; Khandal et al., 2019; Saiteja and Ashok, 2021; Wang et al., 2010);

- RCCl (Reactivity Controlled Compression Ignition) - combustion using mixtures with different chemical activities (Duraisamy et al., 2020; García et al., 2020; Kakaee et al., 2016; Mikulski et al., 2018; Reitz and Duraisamy, 2015);

- TWC (Three-Way Catalytic Converter) - high performance catalytic reactors (Heck and Farrauto, 2001; Keav et al., 2014; Santos and Costa, 2008);

- DPF (Diesel Particulate Filter) - particulate filters for compression ignition engines (Bensaid et al., 2011; Guan et al., 2015; Khair, 2003; Myung et al., 2009);

- GPF (Gasoline Particulate Filter) - particulate filters for spark ignition engines (Joshi and Johnson, 2018; Ko et al., 2019; Lambert et al., 2017; Xia et al., 2017; Yang et al., 2018);

- SCR (Selective Catalytic Reduction) - selective catalytic reduction systems (Forzatti, 2001; Guan et al., 2014; Latha et al., 2019; Li et al., 2011). 
Using this type of system causes considerable complications in the construction of the drive unit and further increasing the costs associated with vehicle manufacturing. In the majority of cases, the reduction level of harmful emissions is, however, not fully satisfactory. Another option is the use of alternative propulsion sources. A number of solutions have been developed over the years, including the use of fuels so that the combustion process is less harmful to the environment, the development of hybrid systems combining an internal combustion engine with another source of propulsion, or using only propulsion systems which do not require combustion. Among the fuels enabling to obtain lower emission results, the liquefied petroleum gas (LPG) (Ashok et al., 2015; Beik et al., 2020; Usman et al., 2020) and compressed natural gas (CNG) (Weaver, 1989; Yeh, 2007) should be mentioned as important ones. Conversion of an internal combustion engine to operate with LPG is popular in the case of passenger cars, although this is not favoured in the more complicated design of the engines. (Borawski, 2015; Mitukiewicz et al., 2015; Szpica et al., 2014). CNG gas as a fuel is more commonly applied in commercial vehicles as well as in work machines (Thiruvengadam et al., 2018). Hybrid systems typically use a combination of an internal combustion engine with an electric drive, nowadays the majority of manufacturers offer vehicles with this type of power system (Hannan et al., 2014; Raslavičius et al., 2017). A less common solution combines a combustion engine with a pneumatic or hydraulic drive (http:/www.groupe-psa.com). In this configuration of the system, energy is accumulated in the form of a pressurised fluid. Drive systems use a hydraulic drive combined with an internal combustion engine enable a high potential for emission reduction through braking energy recovery (Baseley et al., 2007; Zhou et al., 2020). In the case of propulsion systems which do not require a combustion process, fully electric cars predominate and considerable emphasis is also being placed on the development of cars powered by fuel cells (Manoharan et al., 2019; Raslavičius et al., 2015). Vehicles powered only by pneumatic propulsion have not gained significant popularity so far.

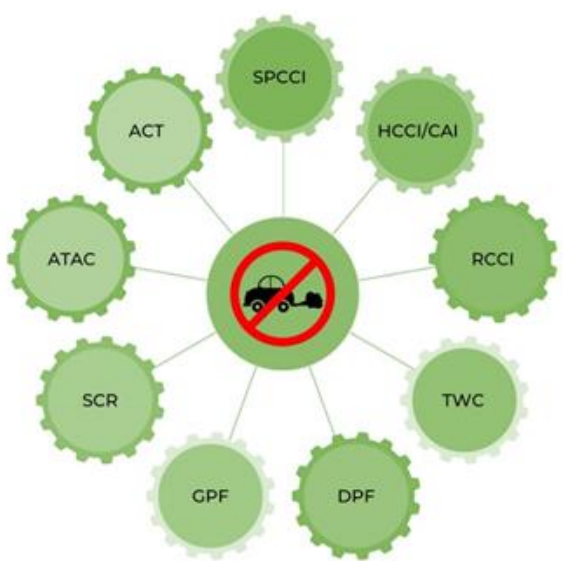

Fig. 1. Solutions applied by automotive companies to reduce exhaust emissions

The idea of using compressed air to power vehicles is not new, which dates to the middle of the 19th century (Mishra and Sugandh, 2014). Although the first attempts in a new type of propulsion, carried out on a passenger vehicle by French inventors Andraud and Tessie of Motay (Wasbari et al., 2017), were successful, this solution has not gained popularity. Only the tramway powered by compressed air, developed by Ludwik Mekarski, made this type of propulsion more widespread (Thipse, 2008). It had an innovative heating system for the supplying air using a steam heater, which eliminated the problem of freezing of drive train components caused by the expansion of air (https://www.tramwayinfo.com). Initial tests were carried out on the streets of Paris, while in 1879 in the city of Nantes, vehicles powered by compressed air were introduced into the developing tramway network. The new type of public transport grew in popularity, and over the following years the fleet of Mekarski trams expanded to 94 units only in the city of Nantes (https://www.tramwayinfo.com). Similar solutions of tramways, as well as locomotives of other designers, have found applications in many large cities in the world such as London and New York among others. With the intensive development of the urban electricity network in the early 20th century, compressed air tramways were gradually replaced by electrically powered vehicles. However, it did not lead to a complete suspension of the development of rail vehicles powered by compressed air. They were widely used in mines and other places where other types of power supply were not able to work, e.g. in the construction of tunnels. The H. K. Porter Company started to introduce compressed air powered locomotives for use in mines from the end of the 19th century (https://americanindustrialmining.com). By using an engine in which the air was expanded in two stages, the range between refilling the air tanks was significantly increased. For many years, this type of propulsion system had no alternatives in places requiring special working conditions. The first attempts of building a car powered by compressed air engines date to the turn of the 1920s and 1930s. (Wasbari et al., 2017). Some of the engine solutions have been patented (Archer, 1929; Eliot, 1934; Friar and Holdcroft, 1925; Wittig, 1925), but none of them entered into serial production. The reasons for this are due to the dynamic development of combustion engines and the unlimited access to fossil fuels. The interest in the compressed air engine subject revived with the fuel crisis of the 1970s. Again, attempts were made to implement a new type of propulsion system for cars. The inventors have patented several solutions (Brown, 1972; Cestero, 1985; Johnson, 1983; Miller, 1980; Wagner, 1975). In the early 1990s, French engineer Guy Negre, the founder of MDI company, began work on a prototype of a vehicle powered by compressed air. Over the years, MDI has made several prototypes of small vehicles with a range reaching up to $200 \mathrm{~km}$, although serial production has not been undertaken (https://www.mdi.lu). Inventor Angelo Di Pietro has developed a design for an unconventional pneumatic engine which is ready to be implemented in vehicles (https://www.engineair.com.au; Di Pietro, 1999). During the entire period of motor vehicle development, work on compressed air power solutions has been repeatedly revisited. However, it usually did not lead to the initiation of serial production on a mass scale. Following the current trends in emissions reduction, it is possible to forecast the prospect of long-term development of alternative power sources, including pneumatic engines (Shi et al., 2016).

\section{PRIMARY ASPECTS OF PNEUMATIC DRIVES}

\subsection{Ecological Aspects}

The compressed air engine concept is a zero-emission drive, the only product of its operation is the air cooled by the expansion process. In fact, similarly to electric drives, it transfers the problem 
of emissions from the engine itself, to the stage of energy generation. The emissivity of pneumatic drives is mainly dependent on the method of producing compressed air. With the use of energy from renewable sources, it is possible to achieve zero-emission propulsion. This is facilitated by the multitude of solutions for air compression equipment, as well as the types of power supply. The simplest system is powering an electric compressor with energy created by photovoltaic panels or a wind power plant. Similar solutions are used in compressed air energy storage (CAES) systems (Budt et al., 2016; Luo et al., 2014; Wang et al., 2017; Zhou et al., 2019) to store energy using compressed air. The operation of this system is based on the compression of air at a time of low electricity demand and storing it in underground tanks (Lund and Salgi, 2009). At the time of increased electricity consumption, the compressed air powers the generators which produce electricity. These solutions, similarly to pneumatic drives, are still in the developmental stage, their major problems are the temperature changes during compression and expansion processes, and the losses associated with this. Despite these adversities, so far there are already two facilities in the world using this technology (Chen et al., 2016). At the current stage of development, facilities of this type cannot replace other sources of electricity generation and storage, although they can significantly help to relieve them, which would also contribute to reducing the harmful effects of human activity on the environment. A similar situation occurs with pneumatic drives.

Powering the air compressor with an internal combustion engine contributes to increasing the overall emissivity of the pneumatic drive. However, it should be emphasised that the internal combustion engine used to drive the compressor could be operated in a 'phlegmatic' drive mode, within a limited range of specific rotational speeds. In such a case, it is possible to optimise the drive system to a high level in terms of emissivity and fuel consumption.

A further important environmental aspect is the materials from which the compressed air engine can be manufactured. As opposed to the internal combustion engine or electric motor, the pneumatic engine during operation does not become warm, instead cooling as a result of air expansion. During long operation, this may lead to the freezing of certain components, in particular the exhaust manifold. The problem can be simply solved by heating the supply air or using a heat exchanger. In comparison to other drive units, it results in a reducing temperature range in which the engine operates, thus the engine design does not require the use of materials with high resistance parameters and sufficient thermal expandability under varying thermal load (Borawski, 2020; Mieczkowski, 2016a; Myagkov et al., 2014). The possibility of using commonly available engineering materials for the design of the propulsion system has a wide-ranging environmental impact. Specialised materials involve the use of admixtures of elements rarely found in the environment, which extraction and processing often requires the consumption of large amounts of energy. The extraction of these raw materials is also associated with irreversible environmental impacts. If the raw material is only found in a few places on earth, an additional factor generating further emissivity arises - transport to the place of further processing (Sen et al., 2019). The use of unconventional materials in design, which require complex technological processes, also contributes to the complication of repairs of components. It often contributes to the fact that the repair of a component is economically unviable. As a result, the operating period of the product is reduced. Used, end-of-life components cannot always be recycled or utilised, and even if they can, the process is not as easy as with typical engineering materials (Harper et al., 2019). This once again results in the generation of pollution. All of this contributes to generating a carbon footprint even before the vehicle is used, which often is not taken into account in assessing the emissions performance of a specific fuel type (Hawkins et al., 2013). Today, the field of materials science is developing at a dynamic rate, and new materials are created with taking into account environmental issues during their design. Nevertheless, engineers still have to make compromises between the selected parameters. For materials with low strength requirements, it is easier to find a substitute in the form of an alternative raw material, which can be partly made of recycled materials.

The other advantage of running in a lower operating temperature range is the lack of need to use viscosity grade oils in the drive unit (Gołębiowski et al., 2019a, 2019b, 2018). The functional properties of oil in pneumatic engines are only limited to lubrication of the cooperating parts and there is no need for oil to dissipate heat from thermally stressed components. For many years, internal combustion engine manufacturers have been trying to extend oil change intervals by using long-life oils. Studies demonstrate that this does not always have a positive effect on the life span of the drive unit (Kral et al., 2014). In a compressed air powered engine, there is no combustion process which mainly causes oil contamination, directly contributing to the degradation of the lubricant. It enables to extend the maintenance interval of the vehicle. According to MDI Company, for the engine designed by them, one litre of vegetable oil allows to use the engine for $25,000 \mathrm{~km}$ (https://air-volution.com.au). From an environmental point of view, this is a considerable reduction in the pollutants generated during the production of synthetic oils. In case of leakage from the engine, vegetable oil causes no harmful effects on nature and its eventual release into the groundwater will not pose a threat of pollution of the environment. It also solves the problem of used oil utilisation, which with the current lubricants used in internal combustion engines contributes to environmental degradation.

A similar situation occurs with the cooling system, the compressed air engine does not require a cooling system using a liquid due to the absence of high temperatures. This eliminates the consumption of one of the basic operating fluids, whose production and possible leaks also contribute to environmental damage. Over the lifetime of the vehicle, assuming an average cooling system volume of approximately 7 litres, and a fluid change of the entire system every 2 years, the savings per vehicle will be significant (Hudgens and Bustamante, 1993). Regarding electric vehicles, as a substitute for engine cooling, the problem of maintaining an adequate temperature of the battery pack has to be taken into account. As the temperature decreases, the efficiency of the battery declines, leading to a reduction in the vehicle's range, whereas excessively high temperatures may lead to overheating dangerously. For this purpose, thermal management system (TMS) systems are created to maintain the specified temperature in the battery unit (Pesaran, 2001; Zhao et al., 2020). Currently there are various TMS solutions in use, some of the most efficient are active systems using a liquid like glycol or gas like refrigerant R134a (Katoch and Eswaramoorthy, 2020; Kim et al., 2019). Despite testing of the use of an environmentally friendly substance for this purpose, the problem is still not solved, and further efforts to improve a vehicle's range and reduce recharge times may result in the need for active systems (Wu et al., 2019). In comparison to electric and internal combustion engines, pneumat- 
ic engines generate zero or minimal environmental impact in this aspect.

Considering the environmental aspects of an air engine, it is important to pay attention not only to the emissivity of the compressed air preparation stage itself, but also to the overall view of the issue. The simplicity of the design and the low strength requirements of the drive unit components contribute to a significantly lower impact on environmental degradation.

\subsection{Economic Aspects}

The development of pneumatic drives has repeatedly been displaced by other, more promising types of drives. Partly it is due to the economic circumstances characterising the compressed air supply. Pneumatic drives have for years faced problems due to the physical properties of air. Compressed air as an energy carrier has a low energy density, particularly in relation to liquid fuels. A summary of energy densities for currently used vehicle power sources is given in Fig. 2.

It contributes to the demand for a much higher volume of compressed air needed to achieve the same range compared to other propulsion sources. In a study (Creutzig et al., 2009), a comparison of power systems is presented in a city car as an example. The authors conducted the analysis taking into account a number of factors, including the efficiency of each propulsion source. In order to achieve a range of $115 \mathrm{~km}$, the vehicle used for the analysis needed 4 litres of fuel or, equivalently, 780 litres of compressed air. Such a volume requires a significant amount of space in the vehicle for the compressed air tank. An intermediate solution to the problem is the increasing the pressure of the air storage. This raises the problem of the proper design of the tank as well as the losses occurring during the air compression process. Electric vehicles also have an advantage over compressed air power, although the difference with the internal combustion engine is not as pronounced. On comparing the weight of the fuel, the respective weights found to be $4.8 \mathrm{~kg}$ for liquid fuel, $53 \mathrm{~kg}$ for compressed air and $140.3 \mathrm{~kg}$ for electric power. The range of compressed air and electric vehicles is strongly dependent on their total weight, although it should be noted that the weight of the battery does not change with the level of charge. The large weight of the electric battery pack affects the vehicles driveability and worsens its handling, which becomes apparent also during the 'moose' test (Mazumder et al., 2012; Szpica, 2019). Another problem is the losses caused by the change of air temperature when increasing or decreasing its pressure. Compression of air causes an increase in its energy, which in turn increases the temperature of the gas (Zhang et al., 2014). In ideal conditions, the air would have sufficient time to equilibrate the temperature to ambient temperature - the transformation would then be isothermal. In fact, the operation of most compressors has a character closer to an adiabatic conversion, resulting in a higher energy requirement to compress the same amount of air as in an isothermal conversion. Slowdown compression process is not a good solution due to increased vehicle charging time. Another way is to use multistage compressors, in which heat exchangers are used between the individual compression stages to cool the air (Grazzini and Milazzo, 2012; Yang et al., 2013). The air expansion process in the pneumatic engine has an adiabatic character due to its dynamic nature, where air temperature is reduced as a result of the release of energy accumulated in the air. In this case, also the progressive expansion of the air, additionally with heating to equalise the air temperature is beneficial. In practice; this solution consists of first reducing the air pressure from the value at which it is stored in the tank to an intermediate pressure, and then reducing the pressure to the working pressure prevailing in the engine and heating it before performing work.

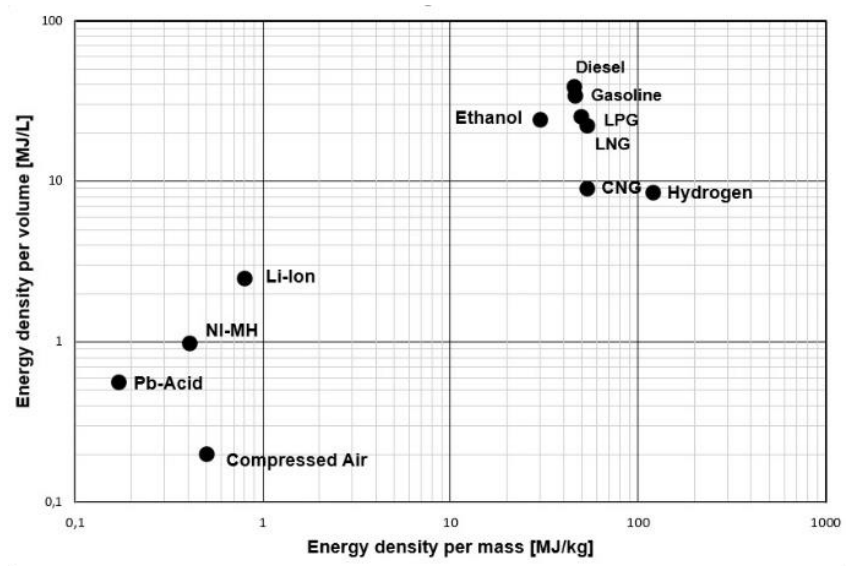

Fig. 2. Summary of energy density parameter for different power sources (Papson et al., 2010)

The economy of pneumatic drives is highly dependent on the achieved efficiency. The designs achieving low efficiency are not only economically unjustifiable, but may also be ultimately environmentally unfriendly as they require significantly more energy in comparison to other propulsion sources. The key to achieving the right efficiency is the appropriate use of available technology to eliminate compression and expansion losses. In addition, compressed air powered engines are not extensively researched, in relation to internal combustion engines or electric drives. There are not many studies dedicated to the evaluation of the impact of power supply conditions on compressed air engine performance. Commercial constructions demonstrate the validity of this type of drive. Developing existing units and new designs can provide measurable benefits in terms of economy.

\subsection{Safety Aspects}

Until now, official crash test of a vehicle powered by compressed air has not been conducted. In terms of design requirements, the bodywork of such a vehicle does not differ from the currently used solutions. The difference is the presence of a compressed air tank, which has to comply with a number of safety requirements. Compressed air storage in pressure tanks is a wellknown, widely used issue. In the case of vehicles, an important element is the proper installation of the tank, ensuring its stable position in the vehicle and protecting it against damage or tearing out. Over the years, the necessary standards and norms have been developed for steel and composite tanks respectively, allowing for safe operation. Inspection of the tanks occurring during the mandatory technical inspection of the vehicle would ensure an appropriate interval for checking the condition of the tank. Legislative standards require an assumed operating lifetime over a minimum of 15 years when calculating the strength of the tank. Regarding LPG gas systems, the approval for the tank is only issued for 10 years, after which the tank must be replaced or renewed, 
approval for CNG gas the lifetime is 20 years. The warranty period for the battery in currently manufactured electric vehicles is a maximum of 10 years, applicable to only a few manufacturers. However, this does not mean that the battery is no longer usable, although it should be noted that over the years, batteries lose their capacity. This adversely affects the vehicle range, causing more frequent charging, which also contributes to the deterioration of the batteries performance (Hoke et al., 2011). The cost of a new battery pack for an electric car is significantly greater than the replacement of a steel or even composite air tank. Another important element responsible for safety in a vehicle using pneumatic drive is the safety valve. Its operation shall be periodically inspected to ensure that the pressure in the tank cannot rise above the admissible level. If the admissible value is exceeded, which can occur when refilling the compressed air, the valve starts with bleed air until the safe pressure is reached, at which it will automatically close (Crosby Valve Inc., 1997). This solution is much safer than charging the battery of an electric vehicle, which in extreme cases of overcharging can result in a potential fire. Analysing extreme cases of hazards related to the compressed air supply system, attention should be primarily focused on bursting of tanks under high pressure as a result of defects. Compressed air, as opposed to other gases used as propulsion sources, is non-flammable, therefore there is no risk of ignition even if a large volume is released in a short period of time. A real health risk for people in the surroundings is the high sound level during an explosion. To ensure safety, the tank shall be mounted on the vehicle in such a way to minimise the possibility of physical damage to the tank while the vehicle is running. (Thipse, 2008).

\subsection{Charging Network for Pneumatic Drives}

One of the main problems of developing every vehicle power source is the absence of a charging or refuelling station. In many cases, this is the main reason for the limited popularity of a particular power source and the consequent reduction of its development rate. The expansion of the drive is also strongly influenced by all kinds of taxes relief or other forms of incentives for the development of the necessary infrastructure, a good example of which in recent years is the development of electric drives and the emergence of charging stations (Foley et al., 2010; Morrow et al., 2008). Today, almost every service station has an air compressor, commonly used to pump up a vehicle tyre. The maximum operating pressure of most of the used compressors is only 6 bar, which is below the operating pressure of the pneumatic engine, and definitely lower than the pressure prevailing in the air tanks of the existing prototype vehicles. However, there are devices available to increase the pressure obtained in a compressor, called pressure intensifiers, which could achieve a pressure sufficient to fill the tanks of some of the current prototype designs. This could enable current stations to have a simple and low cost adjustment to power prototype vehicles. Similar solutions could also be applied in other places with compressed air supply infrastructure, such as industrial plants. In the case of pneumatic vehicles, which also allow for the use of the engine as a compressor, an electric vehicle charging station could be used to fill the compressed air tanks. In such a case, an electric engine powered from the charger drives the pneumatic engine. The recharge time then depends on the efficiency of the engine mode of operation as a compressor.

\section{COMPRESSED AIR POWERED ENGINES}

\subsection{Company Engine}

The company MDI, founded by engineer Guy Negre, has designed a compressed air piston engine from basic (Thipse, 2008). The engine has pistons with different diameters in an in-line arrangement (Fig. 3). The number of cylinders in the engine has changed over the years as the power unit has developed, but the principle of operation has remained the same.

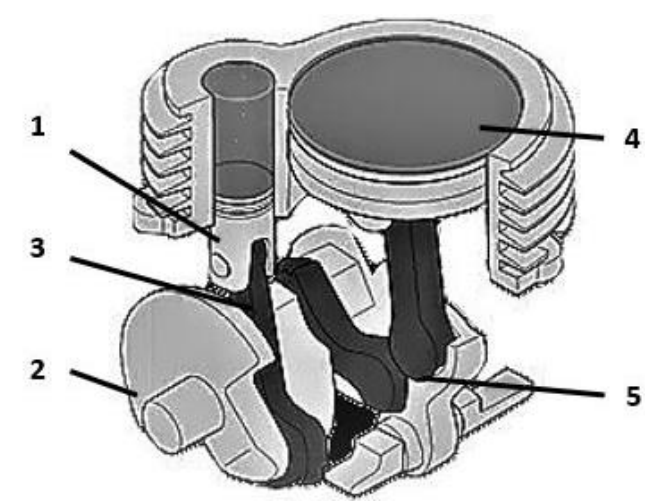

Fig. 3. MDI engine scheme, 1 - piston with smaller diameter, 2 - crankshaft, 3 - connecting rod, 4 - larger piston, 5 - connector, (http://www.thefuture.net.nz)

The piston (1), with a smaller diameter, is connected to the common crankshaft (2) by a conventional connecting rod (3). Second, larger piston (4) uses an additional connector (5), which changes the kinematics of the piston motion. The purpose of this modification is to lower the piston velocity when approaching the Top Dead Centre (TDC), thus increasing the time of filling the cylinder. Engine operation starts with the opening of a valve, allowing the smaller piston to be supplied with compressed air from the tank. Air at a pressure of 20 bar fills it until it reaches the Bottom Dead Centre (BDC), then the supply valve is closed. The air is pushed into a larger cylinder, however it does not cool excessively due to the small change in pressure. It fills initially the cylinder, then mixes with the supply air from the tank, preheating it, thus improves efficiency. Then both pistons move in order to empty the expanded air. The exhaust system only releases lowtemperature air. The engine also features an air heating mode, resulting in a significant increase in the vehicle range. This occurs at the cost of emissions - the system uses a combustion process to heat the air. Fuel consumption is not high and to double the vehicles range it is around $0.3 \mathrm{~L} \mathrm{~km} / 100 \mathrm{~km}$, however the drive is not fully combustion free anymore. The design of the engine, after reversing the operating cycle, allows it to be used also as a compressor for filling the compressed air tank. The currently offered engine variant has a displacement of $430 \mathrm{~cm}^{3}$, which generates $7 \mathrm{~kW}$ and $45 \mathrm{Nm}$ of torque at $1500 \mathrm{rpm}$ (https://www.mdi.lu). The vehicle has a maximum range of $120 \mathrm{~km}$, using only compressed air. A major advantage is the recharging time - when using a station with compressed air, it takes about 2 min to fill the tank. Alternatively, the car can be connected to an electric car charging network, or to an electrical socket in the garage. In this case, the pneumatic engine is used as a compressor to fill the tanks, with a full charge time of $3.5 \mathrm{~h}$. 


\subsection{EngineAir Company Engine (Di Pietro Engine)}

An example of an unconventional engine powered by compressed air is the engine developed by the inventor Angelo Di Pietro. The solutions used in this engine resemble the design of a Wankel engine. The engine (Fig. 4) features a single piston (1), fixed to the shaft by special bearings (2), enabling an eccentric movement during operation (Zwierzchowski, 2017). It operates in an engine cylinder with moving vanes (3). Through the use of springs, the vanes are always pressed against the piston, creating six sealed chambers in which the air is expanded.

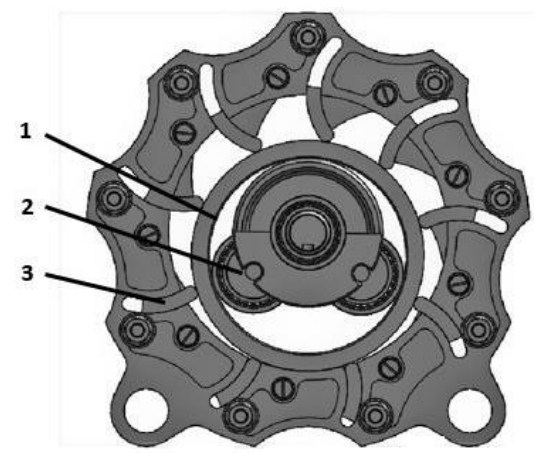

Fig. 4. Di Pietro engine, 1 - piston, 2 - bearing, 3 - vane (Zwierzchowski, 2017)

Supply air is distributed to the individual chambers by means of a rotating cone-shaped element. The operation is based on the expansion of air in successive chambers, thus exerting a force on the outer part of the piston. This sets it in eccentric motion causing, due to its construction, a rotation movement of the output shaft. As the air expands in the chamber, the piston movement causes the opposite chamber, in which work has been done in an earlier cycle, to become empty. Properly selected play between the moving vanes and the cylinder, as well as the operation in pressurised air, allows to maintain a low friction coefficient. This has a very positive effect on engine performance. According to the manufacturer's claims, the engine is able to operate even at a very low pressure of 0.07 bar (https://www.engineair.com.au). Another advantage is the constant torque, which is easily controlled by changing the supply pressure. The engine is characterised by compact dimensions and a low weight of $6 \mathrm{~kg}$. The manufacturer specifies a maximum torque of $40 \mathrm{Nm}$ at a supply pressure of 8 bar. It is possible to increase the engine performance by expanding the dimensions of the working elements (https://www.engineair.com.au).

\subsection{Scroll Engine}

Another example of an unconventional engine is a design based on the design of a scroll compressor (Ivlev and Misyurin, 2017; Liu and Wu, 2015). The concept of the scroll compressor was developed at the beginning of the 20th century, however the technological possibilities needed for serial production were developed only in the 1970s. The solution though widely used in the refrigeration industry, did not gain popularity as a component for supercharging of an internal combustion engine despite its many advantages. In the design (Fig. 5), two spirals are used - one is fixed (1), and the second performing an eccentric movement (2) resulting from the connection to the crankshaft having a minor crank. The motion of the scroll leads to drawing air and the subsequent compression due to the tightening of the space between the scrolls. The compressed air outlet is located in the centre of spiral (3). Spirals do not contact each other during operation, so there is no need for lubrication. It also contributes to quiet operation of the unit.

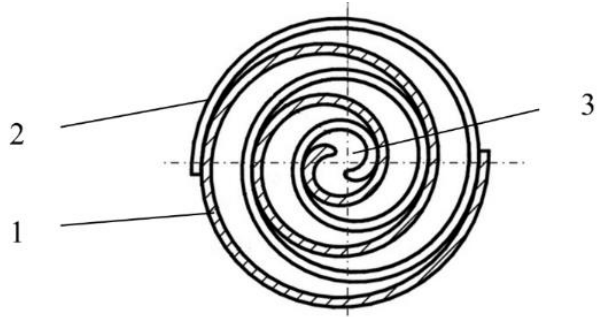

Fig. 5. Scheme of a scroll compressor, 1 - fixed spiral, 2 - moving spiral, 3 - compressor outlet (Liu and Wu, 2015)

The simple design allows the compressor to be easily converted into a pneumatic engine - by supplying compressed air to the compressor outlet (3), the working cycle is reversed. The air then expands in the chambers created between the spirals, starting from the centre. The pressure of compressed air acts on the moving spiral, causing it to move, which creates torque on the shaft to which it is attached. The air is expanded from the inside of the spiral to the outlet at the outer diameter, in successive chambers, thus reducing losses in comparison with a piston engine. In the study (Sergaliyev and Khajiyeva, 2017) the parameters of an engine based on a scroll compressor were examined, the results showing a high specific air consumption, which indicates the expected high performance of the drive. In the literature although many studies on scroll compressors are found, very few items focus on their application in reverse operation. Despite this, scroll engines are one of the more promising solutions. The cost of manufacturing components remains a major problem, despite technological developments.

\section{HYBRID SYSTEMS USING AIR ENGINES}

In spite of the numerous advantages of the pneumatic engine, a significant problem remains in achieving adequate efficiency as the sole source of drive. This leads to the development of using pneumatic drives as an additional power source in hybrid systems, or using compressed air as a source to improve the efficiency of the internal combustion engine (Dimitrova and Maréchal, 2015). Propulsion systems of this type do not require large compressed air tanks, and the range of the vehicle on both types of power supply is similar to internal combustion vehicles. An additional advantage is the possibility to use the vehicles kinetic energy during engine braking to charge the compressed air tanks, similar to hybrid systems combining an internal combustion engine with an electric drive, which also has a positive effect on the wear of the brake system components (Borawski, 2018).

Researchers at ETH Zurich (Guzzella et al., 2010) presented a concept for a pneumatic hybrid system using a downsized supercharged internal combustion engine as the power source. In downsized engines, there is a common problem with the occurrence of turbo lag, caused among other things by the inertia of the 
supercharging system. In order to eliminate it, twin charger using mechanical charging and a turbocharger, turbochargers with variable geometry vanes, or twin-turbo systems with turbochargers are used. All these solutions significantly increase the complexity and cost of engine design. The concept from ETH Zurich is an alternative solution that allows the supercharging system to be supported by compressed air stored in a tank. The object of the research was a twin-cylinder turbocharged engine with a displacement of $0.75 \mathrm{dm}^{3}$ and power of $61 \mathrm{~kW}$. It was subjected to a modification (Fig. 6) consisting in the replacement of one of the two exhaust valves by a valve called Charge Valve (1).

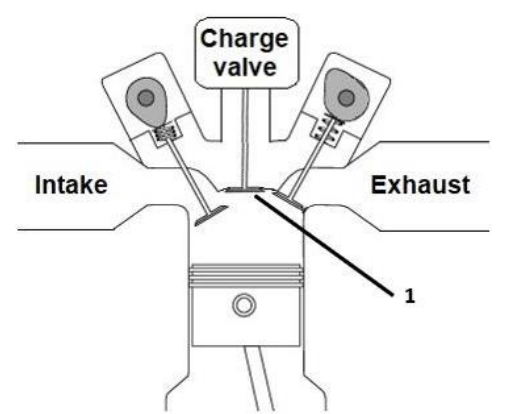

Fig. 6. Concept of pneumatic hybrid system, 1- charge valve (Guzzella et al., 2010)

This valve, as opposed to the others, is electro-hydraulically operated. It is connected to a compressed air tank with a capacity of 30 litres. The engine can be operated in combustion mode as well as in compressed air mode. The highest performance is achieved in the combined mode - called supercharged mode. This mode involves opening an additional valve during the compression stroke to allow compressed air to be admitted into the cylinder in order to inject more fuel. It has a positive effect on the torque curve, eliminating the air deficiency at lower rotational speeds caused by the turbocharger's operating characteristics. As a result, it is possible to reduce the engine's displacement, which indirectly contributes to reducing combustion. Supercharged mode is only used during low rotational speed engine conditions to assist the turbocharger. The compressed air supply can also be used to start the engine, the response time is then faster than in the case of the combustion mode, which is important when using a start-stop system. The test results showed a reduction in combustion in the NEDC driving cycle of around 30\%.

Another example of the use of air propulsion in a hybrid system is the Hybrid Air drive developed by the PSA Group (https://www.groupe-psa.com; Wasbari et al., 2017). It uses a combination of three types of power supply (Fig. 7) - combustion, hydraulic, and pneumatic (compressed nitrogen is used instead of air). The basic drive is a three-cylinder spark-ignition engine (1), supported by a hydraulic drive (3). Compressed nitrogen is used in this case for energy storage. The drive system consists of a hydraulic pump with a hydraulic motor (3) hydraulic fluid tank (5), expansion chamber (4), and summation gearbox (2). The system has three operating modes: combustion mode, air mode and combined mode. In air mode, the vehicle is driven by a hydraulic motor, supplied with hydraulic fluid, which is compressed in an expansion chamber by expanding nitrogen from a tank. This mode is used at velocities $<70 \mathrm{~km} / \mathrm{h}$. During braking, the wheels drive a hydraulic pump which pushes hydraulic fluid into the expansion chamber and compresses the nitrogen, which acts as an energy accumulator. Combined mode is used when accelerating and driving dynamically, and then the hydraulic motor supports the combustion engine. Internal combustion engine only mode is used when travelling at constant velocities, for example, when driving on a highway.

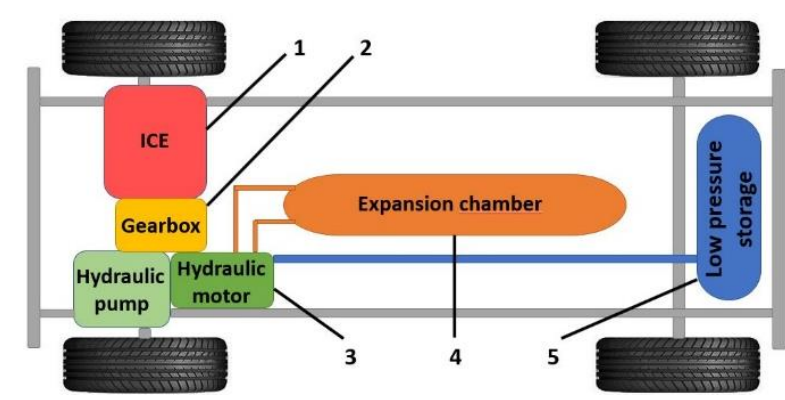

Fig. 7. PSA hybrid system scheme (https://www.groupe-psa.com; Wasbari et al., 2017)

This solution is similar in its properties to electric hybrids. The manufacturer declares a reduction of fuel consumption by $45 \%$ in the urban cycle and by $35 \%$ in the mixed cycle (https://www.groupe-psa.com). Hydraulic drives have been used for many years in heavy-duty machinery, making them a welldeveloped type of power supply, which is a big advantage over electric drives. The problem with the design is the requirement of large amount of space for the compressed nitrogen tank and with the current size of the system, makes only sense for small and light vehicles.

Researcher K.D. Huang presented a series of studies on hybrid propulsion systems combining an internal combustion engine with a pneumatic engine (Huang et al., 2005; Huang and Tzeng, 2005). The scheme of the system is presented in Fig. 8. The solution uses a four-stroke internal combustion engine with a displacement of $125 \mathrm{~cm}^{3}$, operating at a constant rotational speed for supplying the compressor that compresses the air into the tank.

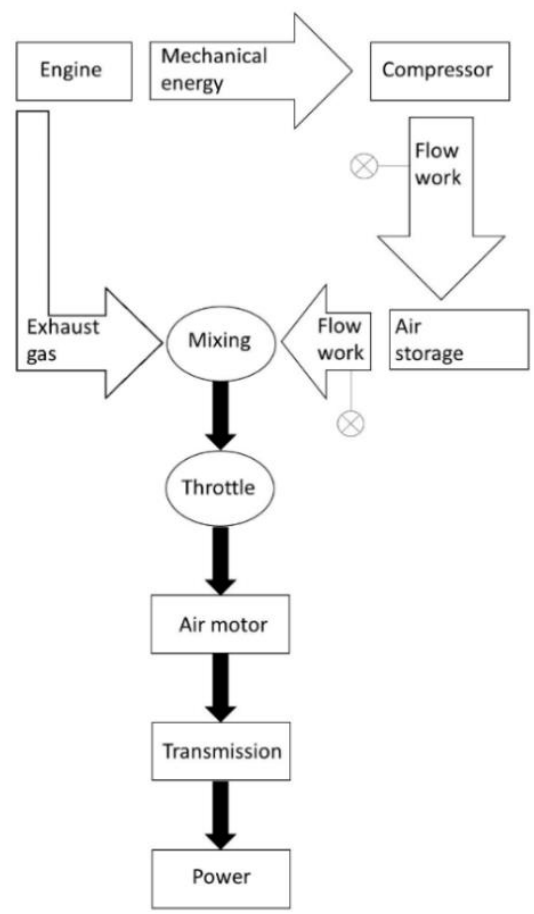

Fig. 8. Block diagram of the hybrid system presented by K. D. Huang (Huang and Tzeng, 2005) 
Its function is to equalise pressure and store air. Then the compressed air is dosed by a throttle into the manifold, depending on the current power requirement, where it is expanded at first. The difference with other solutions is the use of a mixing chamber in the manifold of the pneumatic engine. The compressed air is mixed inside with the exhaust gases from the internal combustion engine before entering into the cylinder of the pneumatic engine. This ensures that the heat generated by the internal combustion engine is used to heat the air that directly supplies the pneumatic engine, improving the efficiency of the entire system. In the internal combustion engine, the heat balance is improved; the author declares using about $60 \%$ of the waste heat, which contributes to increasing its efficiency. Heating the compressed air before it expands in the cylinder increases the efficiency of the pneumatic engine. The internal combustion engine operating at a constant load can be optimised with regard to fuel consumption and the reduction of exhaust gases by running at the optimal rotational speed in terms of efficiency. Experimental investigations demonstrated an improvement of the drive parameters in relation to the operation of the system without the use of the mixing chamber by about $20 \%$.

\section{CONVERSION OF INTERNAL COMBUSTION ENGINE TO COMPRESSED AIR SUPPLY}

Many references in the literature can be found on the conversion of the internal combustion engine to compressed air supply. Due to the nature of their work, as well as their simple design, in most cases two-stroke engines are modified (Kumar et al., 2014; Szpica and Korbut, 2020, 2019). However, studies on the conversion of four-stroke engines can also be found (Huang et al., 2013; Nabil, 2019). The idea of the conversion is to generate the force acting on the piston by means of compressed air instead of the combustion process. For this purpose, the engine supply system must be completely changed (Fig. 9). As an element supplying compressed air, solenoid valves 4 are most frequently used, while more rarely the valves opened mechanically as a result of the rotation of the crankshaft. The reason for this is that the solenoid valve enables the compressed air supply to be started independently of the angle of rotation of the crankshaft, which is important for optimising the efficiency parameters of the engine. If the valve opening and closing times need to be shortened, piezoelectric actuators can be used (Caban et al., 2020; Mieczkowski, 2016b). It is usually mounted in place of the spark plug (5), which is superfluous in the case of an air engine. Additional advantage of this solution is the compressed air intake located directly above the piston. The supply system also includes a pressure regulator (3), which reduces the pressure from the compressed air tank (1) to the specified supply pressure.

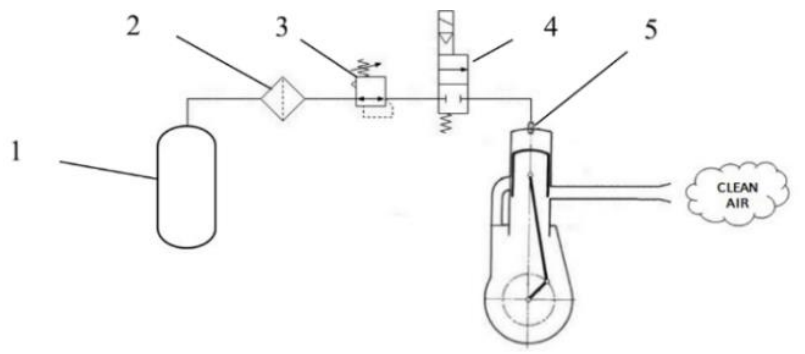

Fig. 9. Scheme of example for modification of an engine supply system to operate with compressed air, 1 - compressed air tank, 2 - filter, 3 - pressure regulator, 4 - solenoid valve, 5 - intake of compressed air

Filter (2) is an important part of the supply system, aimed to remove solid particles and condensate from the air. Depending on the type of engine design, additional modifications may be necessary. In the case of two- stroke engines, this includes the provision of lubrication to the engine, as normally the fuel mixture is used for this purpose. Conversion of a four-stroke engine involves a change in operating mode to a two-stroke as, for instance, there is no need to compress the charge. This requires modifications in the timing system (Szoka and Szpica, 2012) and, in the case of direct supply of compressed air to the cylinder, blanking of the intake valves. The timing should ensure the opening of the exhaust valves with every revolution of the crankshaft. Studies also demonstrate the validity of lowering the compression ratio in comparison to an internal combustion engine, using, for example, pads between the engine head and engine block (Kamiński et al., 2020). The conversion of an engine, in particular a two-stroke engine, does not require high financial costs (Nabil, 2019). This allows for the use of parts from existing engines to build propulsion units that do not require combustion. Adequate adjustment of the power supply parameters of the pneumatic engine makes it possible to approach its external indicators to the base combustion units. The results obtained by the researchers (Kumar et al., 2014; Radhakrishna and Gopikrishna, 2017; Wang et al., 2014), presented in Tab. 1, indicate that at higher rotational speeds the efficiency parameters of the pneumatic engine decline. The power achieved is low compared to the base engine, while the torque is comparable. Pneumatic drives are one of the most underdeveloped types of drives and further research may have a positive impact on their performance parameters (Warguła and Kukla, 2020).

Tab. 1. Comparisons of performance results for engines converted to compressed air supply

\begin{tabular}{|c|c|c|c|c|c|}
\hline No. & Researcher & $\begin{array}{c}\text { Basic engine } \\
\text { power }\end{array}$ & $\begin{array}{c}\text { Compressed air } \\
\text { engine power }\end{array}$ & $\begin{array}{c}\text { Basic engine } \\
\text { torque }\end{array}$ & $\begin{array}{c}\text { Compressed air } \\
\text { engine torque }\end{array}$ \\
\hline 1 & V. Kumar, N. Kumar (Kumar et al., 2014) & $4.4 \mathrm{~kW}$ & $1.39 \mathrm{~kW}$ & $10.1 \mathrm{Nm}$ & $30 \mathrm{Nm}$ \\
\hline 2 & L. Radhakrishna, N. Gopikrishna (Radhakrishna and Go- \\
pikrishna, 2017) & $2.2 \mathrm{~kW}$ & $0.17 \mathrm{~kW}$ & $2.94 \mathrm{Nm}$ & $1.87 \mathrm{Nm}$ \\
\hline 3 & T. Nabil (Nabil, 2019) & $8.5 \mathrm{~kW}$ & $0.245 \mathrm{~kW}$ & $11.5 \mathrm{Nm}$ & $7.8 \mathrm{Nm}$ \\
\hline 4 & S. Allam M. Zakaria (Allam and Zakaria, 2018) & $3.2 \mathrm{~kW}$ & $1.74 \mathrm{~kW}$ & - & - \\
\hline 5 & C. Huang, C. Hu, C. Yu, C. Yu, C. Sung (Huang et al., 2013) & $5.5 \mathrm{~kW}$ & $0.96 \mathrm{~kW}$ & $7.44 \mathrm{Nm}$ & $9.9 \mathrm{Nm}$ \\
\hline 6 & M. Kamiński, D. Szpica M. Korbut (Kamiński et al., 2020) & $1.84 \mathrm{~kW}$ & $0.36 \mathrm{~kW}$ & $3.5 \mathrm{Nm}$ & $3.1 \mathrm{Nm}$ \\
\hline
\end{tabular}




\section{PERSPECTIVES FOR FURTHER DEVELOPMENT OF PNEUMATIC ENGINES}

The current pneumatic drive designs available on the market working as a single source of propulsion are only capable to power vehicles with limited unladen weight. In addition, their range is lower than currently produced electric vehicles. The situation is different for hybrid systems. Concept studies for the new solutions demonstrate significant improvements in emissions and economy, and the example of PSA's drive train design shows that they have real potential for implementation in production. Similar situation occurred with electric drives in the first decade of the 21st century. The gradual introduction of hybrid drives by manufacturers has convinced customers, among other things, by the low fuel consumption. It has also contributed to the intensification of the development of electric drive technology, which has improved its performance parameters. The direct result of this is the great increase in the popularity of electric drives, and also as the only source of propulsion. The introduction of new exhaust emission limits creates favourable conditions for the development of alternative power sources. The decisive factor is whether the automotive corporations will consider research work towards pneumatic drives.

The numerous developing concepts for complying with the homologation requirements give hope that one of the companies from the automotive industry will undertake the implementation of the topic. Many aspects of air engine operation have not been explored yet, which provides opportunities for further efficiency improvements. The main advantages of pneumatic drives are lower complexity in comparison to electric drives, the possibility of reducing overall emissions, and cheaper construction costs. A positive factor for the chances of pneumatic drives is also the conviction of a clean drive because of operating results only in the form of cooled air. Currently developed concepts of pneumatic drives are shown in Fig. 10. Further development is closely dependent on research work and their results. The road to commercialisation is a long one, making it difficult to expect the rapid appearance of cars powered by compressed air.

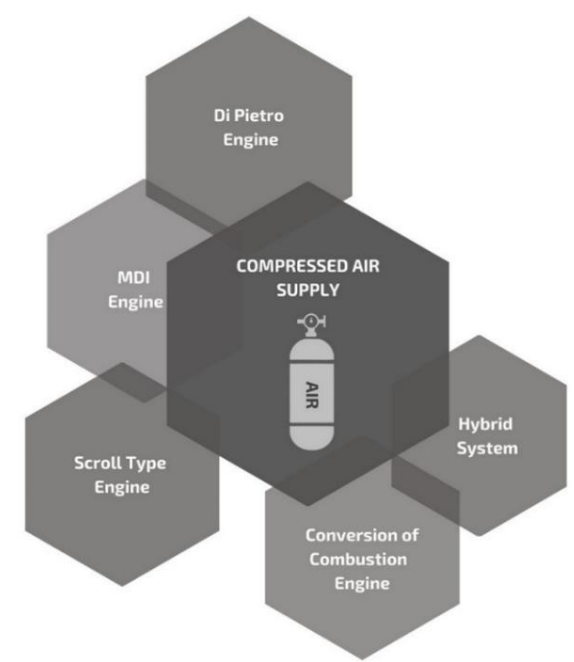

Fig. 10. Currently developed concepts of pneumatic drives

\section{CONCLUSIONS}

The paper focuses on a multi-faceted analysis of pneumatic drives with regard to their application in powering vehicles. Their use is known for many years, although it never gained any significant popularity. Currently, the development and research of pneumatic drives is also negligible compared to electric drives. Forcing manufacturers to look for alternative propulsion sources, and slowly turning away from conventional internal combustion engines, positively impacts on the potential for refocusing on this type of propulsion. The greatest opportunities can be observed in hybrid systems, as evidenced by the PSA Group solution. The use of energy recovery or the improvement of the thermal balance by using the exhaust gases from the internal combustion engine favourably improves the efficiency of the drives. Current technology and solutions do not allow for the introduction into series production of a vehicle powered solely by a compressed-air engine with a range adequate to other sources of propulsion. The MDI or EngineAir company projects indicate that pneumatic drives have potential and could be used in the future as a cheaper and more environmentally friendly alternative to electric drives. Considering the environmental performance of pneumatic drives, it can be observed that they have a much lower impact on environmental degradation. Nevertheless, further development is mainly determined by efficiency improvements, on which future research should focus.

Nomenclature: ATAC, Active Thermo-Atmosphere Combustion; ACT, Active Cylinder Technology; BDC, Bottom Dead Centre; CAES, compressed air energy storage; CAI, controlled auto-ignition; CNG, compressed natural gas; DPF, diesel particulate filter; GPF, gasoline particulate filter; $\mathrm{HCCl}$, homogeneous charge compression ignition; LPG, liquefied petroleum gas; NEDC, New European Driving Cycle; RCCI, reactivity controlled compression ignition; RDE, real drive test; $S C R$, selective catalytic reduction; $\mathrm{SPCCl}$, spark-controlled compression ignition; TMS, thermal management system; TWC, three-way catalytic converter; TDC, top dead centre; WLTP, Worldwide Harmonized Light Vehicles Test Procedure;.

\section{REFERENCES}

1. Akira I., Hideo S. (2004), Analysis of Compression-induced Autoignition Combustion Characteristics of $\mathrm{HCCl}$ and ATAC Using the Same Engine, Journal of Mechanical Science and Technology, Vol. 20, No. 9, 1449-1458.

2. Allam S., Zakaria M. (2018), Experimental Investigation of Compressed Air engine Performance, International Journal of Engineering Inventions, Vol. 7, 13-20.

3. Archer H.B. (1929), US1776963A Compressed-air engine.

4. Ashok B., Denis Ashok S., Ramesh Kumar C. (2015), LPG diesel dual fuel engine - A critical review, Alexandria Engineering Journal, Vol. 54, No. 2, 105-126.

5. Baseley S., Ehret C., Greif E., Kliffken M.G. (2007), Hydraulic hybrid systems for commercial vehicles, SAE Technical Papers, Vol. 2007-01-4150, 1-8.

6. Beik Y., Dziewiątkowski M., Szpica D. (2020), Exhaust Emissions of an Engine Fuelled by Petrol and Liquefied Petroleum Gas with Control Algorithm Adjustment, SAE International Journal of Engines, Vol. 13, No. 5, 1-22.

7. Bensaid S., Caroca C.J., Russo N., Fino D. (2011), Detailed investigation of non-catalytic DPF regeneration, Canadian Journal of Chemical Engineering, Vol. 89, 401-407.

8. Bielaczyc P., Woodburn J. (2019), Trends in Automotive Emission Legislation: Impact on LD Engine Development, Fuels, Lubricants and Test Methods: a Global View, with a Focus on WLTP and RDE Regulations, Emission Control Science and Technology, Vol. 5, No. 1, 86-98.

9. Borawski A. (2015), Modification of a fourth generation LPG installation improving the power supply to a spark ignition engine, Eksploatacja i Niezawodnosc, Vol. 17, 1-6. 
10. Borawski A. (2018), Simulation Study of the Process of Friction in the Working Elements of a Car Braking System at Different Degrees of Wear, Acta Mechanica et Automatica, Vol. 12, No. 3, 221-226.

11. Borawski A. (2020), Conventional and unconventional materials used in the production of brake pads - Review, Science and Engineering of Composite Materials, Vol. 27, 374-396.

12. Brown R. (1972), US3765180A Compressed air engine.

13. Budt M., Wolf D., Span R., Yan J. (2016), A review on compressed air energy storage: Basic principles, past milestones and recent developments, Applied Energy, Vol. 170, 250-268.

14. Caban J., Litak G., Ambrożkiewicz B., Gardyński L., Stączek P., Wolszczak P. (2020), Impact-based piezoelectric energy harvesting system excited from diesel engine suspension, Applied Computer Science, Vol. 16, No. 3, 16-29.

15. Cestero L.G. (1985), US4651525A Piston reciprocating compressed air engine.

16. Chen L., Zheng T., Mei S., Xue X., Liu B., Lu Q. (2016), Review and prospect of compressed air energy storage system, Journal of Modern Power Systems and Clean Energy, Vol. 4, 529-541.

17. Creutzig F., Papson A., Schipper L., Kammen D.M. (2009), Economic and environmental evaluation of compressed - air cars, Environmental Research Letters, Vol. 4, 1-10.

18. Crosby Valve Inc. (1997), Pressure Relief Valve, Engineering Handbook, 1-93.

19. Di Pietro A. (1999), EP1204809B1 Rotary piston engine.

20. Dimitrova Z., Maréchal F. (2015), Gasoline hybrid pneumatic engine for efficient vehicle powertrain hybridization, Applied Energy, Vol. 151, 168-177.

21. Duraisamy G., Rangasamy M., Govindan N. (2020), A comparative study on methanol/diesel and methanol/PODE dual fuel RCCl combustion in an automotive diesel engine, Renewable Energy, Vol. 145, 542-556.

22. Eliot S. (1934), US1954408A Compressed air engine

23. Foley A.M., Winning I.J., Gallachóir B.P. (2010), State-of-the-art in electric vehicle charging infrastructure, 2010 IEEE Vehicle Power and Propulsion Conference, 1-6.

24. Forzatti P. (2001), Present status and perspectives in de-NOx SCR catalysis, Applied Catalysis A: General, Vol. 222, 221-236.

25. Friar T.D., Holdcroft J.F. (1925), GB253219A An improved compressed air engine.

26. García A., Monsalve-Serrano J., Villalta D., Guzmán-Mendoza M. (2020), Methanol and OMEx as fuel candidates to fulfill the potential EURO VII emissions regulation under dual-mode dual-fuel combustion, Fuel, Vol. 287, 1-13.

27. Gołębiowski W., Wolak A., Zając G. (2018), Definition of oil change intervals based on the analysis of selected physicochemical properties of used engine oils, Combustion Engines, Vol. 172, 44-50.

28. Gołębiowski W., Wolak A., Zając G. (2019), The influence of the presence of a diesel particulate filter (DPF) on the physical and chemical properties as well as the degree of concentration of trace elements in used engine oils, Petroleum Science and Technology, Vol. 37, 746-755.

29. Gołębiowski W., Zając G., Wolak A. (2019), Analysis of Engine Oils from Farm Tractors in the Aspect of their Change, Agricultural Engineering, Vol. 23, 25-38.

30. Gosala D.B., Allen C.M., Ramesh A.K., Shaver G.M., McCarthy J., Stretch D., Koeberlein E., Farrell L. (2017), Cylinder deactivation during dynamic diesel engine operation, International Journal of Engine Research, Vol. 18, No. 10, 991-1004.

31. Grazzini G., Milazzo A. (2012), A thermodynamic analysis of multistage adiabatic CAES, Proceedings of the IEEE, Vol. 100, 461472.

32. Guan B., Zhan R., Lin H., Huang Z. (2014), Review of state of the art technologies of selective catalytic reduction of NOx from diesel engine exhaust, Applied Thermal Engineering, Vol. 66, 395-414.

33. Guan B., Zhan R., Lin H., Huang Z. (2015), Review of the state-ofthe-art of exhaust particulate filter technology in internal combustion engines, Journal of Environmental Management, Vol. 154, 225-258.
34. Guzzella L., Onder C., Dönitz C., Voser C., Vasile I. (2010), The pneumatic hybridization concept for downsizing and supercharging gasoline engines, MTZ worldwide, Vol. 71, 38-44.

35. Hannan M.A., Azidin F.A., Mohamed A. (2014), Hybrid electric vehicles and their challenges: A review, Renewable and Sustainable Energy Reviews, Vol. 29, 135-150.

36. Harper G., Sommerville R., Kendrick E., Driscoll L., Slater P., Stolkin R., Walton A., Christensen P., Heidrich O., Lambert S., Abbott A., Ryder K., Gaines L., Anderson P. (2019), Recycling lithium-ion batteries from electric vehicles, Nature, Vol. 575, 75-86.

37. Hawkins T.R., Singh B., Majeau-Bettez G., Strømman A.H. (2013), Comparative Environmental Life Cycle Assessment of Conventional and Electric Vehicles, Journal of Industrial Ecology, Vol. 17, 53-64.

38. Heck R.M., Farrauto R.J. (2001), Automobile exhaust catalysts, Applied Catalysis A: General, Vol. 221, 443-457.

39. Hoke A., Brissette A., Maksimović D., Pratt A., Smith K. (2011), Electric vehicle charge optimization including effects of lithium-ion battery degradation, 2011 IEEE Vehicle Power and Propulsion Conference, 1-8.

40. Hooftman N., Messagie M., Van Mierlo J., Coosemans T. (2018), A review of the European passenger car regulations - Real driving emissions vs local air quality, Renewable and Sustainable Energy Reviews, Vol. 86, 1-21.

41. http://www.thefuture.net.nz/engine.htm [online cit.: 2021.04.15].

42. https://air-volution.com.au/compressed-air-engine/ [online cit.: 2021.04.16].

43. https://americanindustrialmining.com/porter-locomotives [online cit.: 2021.04.14].

44. https://www.engineair.com.au/ [online cit.: 2021.04.15].

45. https://www.groupe-psa.com/en/newsroom/automotive-innovation/ hybrid-air [online cit:: 2021.04.03]

46. https://www.mdi.lu/airpod-2-0 [online cit.: 2021.04.15]

47. https://www.pmreview.com/wpcontent/uploads/2013/01/psa_air_hybri d-1 [online cit.: 2021.04.15]

48. https://www.tramwayinfo.com/Defair.htm [online cit.: 2021.04.15].

49. Huang C.Y., Hu C.K., Yu C.J., Sung C.K. (2013), Experimental investigation on the performance of a compressed-air driven piston engine, Energies, Vol. 6, 1731-1745.

50. Huang K.D., Tzeng S.C. (2005), Development of a hybrid pneumatic-power vehicle, Applied Energy, Vol. 80, 47-59.

51. Huang K.D., Tzeng S.C., Chang W.C. (2005), Energy-saving hybrid vehicle using a pneumatic-power system, Applied Energy, 81, 1-18.

52. Hudgens R.D., Bustamante R.B. (1993), Toxicity and disposal of engine coolants, ASTM Special Technical Publication, 149-164.

53. Ivlev V.I., Misyurin S.Y. (2017), Calculated and experimental characteristics of a scroll machine operating in the air motor mode, Doklady Physics, Vol. 62, 42-45.

54. Jeuland N., Montagne X., Duret P. (2004), New HCCI/CAI combustion process development: Methodology for determination of relevant fuel parameters, Oil and Gas Science and Technology, Vol. 59, No. 6, 571-579.

55. Johnson J.M. (1983), US4596119A Compressed air propulsion system for a vehicle.

56. Joshi A., Johnson T. V. (2018), Gasoline Particulate Filters a Review, Emission Control Science and Technology, 4, 219-239.

57. Joshi M.C., Gosala D.B., Allen C.M., Vos K., Van Voorhis M., Taylor A., Shaver G.M., McCarthy J., Stretch D., Koeberlein E. Farrell L. (2017), Reducing Diesel Engine Drive Cycle Fuel Consumption through Use of Cylinder Deactivation to Maintain Aftertreatment Component Temperature during Idle and Low Load Operating Conditions, Frontiers in Mechanical Engineering, 3, 1-15.

58. Kakaee A.H., Nasiri-Toosi A., Partovi B., Paykani A. (2016), Effects of piston bowl geometry on combustion and emissions characteristics of a natural gas/diesel RCCl engine, Applied Thermal Engineering, Vol. 102, 1462-1472.

59. Kamguia Simeu S., Kim N. (2018), Standard Driving Cycles Comparison (IEA) \& Impacts on the Ownership Cost, SAE Technical Papers, 2018-01-0423, 1-12. 
60. Kamiński M., Korbut M., Szpica D. (2020), Piston pneumatic engine - Preliminary research, Transport Means - Proceedings of the International Conference, Vol. 24, 126-131.

61. Katoch S.S., Eswaramoorthy M. (2020), A Detailed Review on Electric Vehicles Battery Thermal Management System, IOP Conference Series: Materials Science and Engineering, 912, 1- 11.

62. Keav S., Matam S.K., Ferri D., Weidenkaff A. (2014), Structured perovskite-based catalysts and their application as Three-Way Catalytic converters - a review, Catalysts, Vol. 4, 226-255.

63. Khair M.K. (2003), A review of diesel particulate filter technologies, SAE Technical Papers, 2003-01-2303, 1-11.

64. Khandal S. V., Banapurmath N.R., Gaitonde V.N. (2019), Performance studies on homogeneous charge compression ignition $(\mathrm{HCCl})$ engine powered with alternative fuels, Renewable Energy, Vol. 132, 683-693.

65. Kim J., Oh J., Lee H. (2019), Review on battery therma management system for electric vehicles, Applied Thermal Engineering, Vol. 149, 192-212.

66. Ko J., Kim K., Chung W., Myung C.L., Park S. (2019), Characteristics of on-road particle number (PN) emissions from a GDI vehicle depending on a catalytic stripper (CS) and a metal-foam gasoline particulate filter (GPF), Fuel, Vol. 238, 363-374.

67. Kral J., Konecny B., Kral J., Madac K., Fedorko G., Molnar V. (2014), Degradation and chemical change of longlife oils following intensive use in automobile engines, Measurement: Journal of the International Measurement Confederation, Vol. 50, 34-42.

68. Kumar V., Takkar J., Chitransh M., Kumar N., Banka U., Gupta U. (2014), Development of an advanced compressed air engine kit for small engine, SAE Technical Papers, 2014-01-1666, 1-11.

69. Lambert C., Chanko T., Dobson D., Liu X., Pakko J. (2017), Gasoline Particle Filter Development, Emission Control Science and Technology, Vol. 3, 105-111.

70. Latha H.S., Prakash K. V, Veerangouda M., Maski D., Ramappa K.T. (2019), A Review on SCR System for NOx Reduction in Diese Engine, International Journal of Current Microbiology and Applied Sciences, Vol. 8, No. 4, 1553-1559.

71. Lee N., Park J., Lee J., Park K., Choi M., Kim W. (2018), Estimation of fuel economy improvement in gasoline vehicle using cylinder deactivation, Energies, Vol. 11, 1-12

72. Li J., Chang H., Ma L., Hao J., Yang R.T. (2011), Low-temperature selective catalytic reduction of $\mathrm{NOx}$ with $\mathrm{NH} 3$ over metal oxide and zeolite catalysts - A review, Catalysis Today, Vol. 175, 147-156.

73. Ligterink N., Mensch P., Cuelenaere R. (2016), NEDC - WLTP comparative testing, TNO report: TNO, Vol. R11285, 1-29.

74. Liu T., Wu Z. (2015), Modeling of top scroll profile using equidistantcurve approach for a scroll compressor, Mathematical Problems in Engineering, 1-8.

75. Lund H., Salgi G. (2009), The role of compressed air energy storage (CAES) in future sustainable energy systems, Energy Conversion and Management, Vol. 50, 1172-1179.

76. Luo X., Wang J., Dooner M., Clarke J., Krupke C. (2014), Overview of current development in compressed air energy storage technology, Energy Procedia, Vol. 62, 603-611.

77. Manoharan Y., Hosseini S.E., Butler B., Alzhahrani H., Senior B.T.F., Ashuri T., Krohn J. (2019), Hydrogen fuel cell vehicles Current status and future prospect, Applied Sciences (Switzerland) Vol. 9, 1-17.

78. Mazumder H., Al Emran Hassan M.M., Ektesabi M., Kapoor A. (2012), Performance analysis of EV for different mass distributions to ensure safe handling, Energy Procedia, Vol. 14, 949-954

79. Mieczkowski G. (2016), Electromechanical characteristics of piezoelectric converters with freely defined boundary conditions and geometry, Mechanika, Vol. 22, No. 4, 265-272.

80. Mieczkowski G. (2016), Stress fields at the tip of a sharp inclusion on the interface of a bimaterial, Mechanics of Composite Materials, Vol. 52, No. 5, 601-610.

81. Mikulski M., Balakrishnan P.R., Doosje E., Bekdemir C. (2018), Variable Valve Actuation Strategies for Better Efficiency Load Range and Thermal Management in an RCCl Engine, SAE Technical
Papers, 2018-01-0254, 1-14

82. Miller T.R. (1980), US4370857A Pneumatic system for compressed air driven vehicle.

83. Mishra K.R., Sugandh G. (2014), Study About Engine Operated By Compressed Air (C.A.E): A Pneumatic Power Source, Journal of Mechanical and Civil Engineering. Vol. 11, 99-103.

84. Mitukiewicz G., Dychto R., Leyko J. (2015), Relationship between LPG fuel and gasoline injection duration for gasoline direct injection engines, Fuel, Vol. 153, 526-534

85. Morrow K., Karner D., Francfort J. (2008), Advanced Vehicle Testing Activity Plug-in Hybrid Electric Vehicle Charging Infrastructure Review Novem Charging Infrastructure Review, U. S. Department of Energy Vehicle Technologies Program, Vol. 34, 1-40.

86. Muhamad Said M.F., Abdul Aziz A., Abdul Latiff Z., Mahmoudzadeh Andwari A., Mohamed Soid S.N. (2014), Investigation of Cylinder Deactivation (CDA) Strategies on Part Load Conditions, SAE Technical Papers, 2014-01-2549, 1-7.

87. Myagkov L.L., Mahkamov K., Chainov N.D., Makhkamova I. (2014), Advanced and conventional internal combustion engine materials, Alternative Fuels and Advanced Vehicle Technologies for Improved Environmental Performance: Towards Zero Carbon Transportation, 370-392.

88. Myung C.L., Lee H., Choi K., Lee Y.J., Park S. (2009), Effects of gasoline, diesel, LPG, and low-carbon fuels and various certification modes on nanoparticle emission characteristics in light-duty vehicles, International Journal of Automotive Technology, Vol. 10, 537-544.

89. Nabil T. (2019), Investigation and implementation of compressed air powered motorbike engines, Engineering Reports, Vol. 1, 1-13

90. Olesky L.M., Lavoie G.A., Assanis D.N., Wooldridge M.S., Martz J.B. (2014), The effects of diluent composition on the rates of $\mathrm{HCCl}$ and spark assisted compression ignition combustion, Applied Energy, Vol. 124, 186-198.

91. Onishi S., Jo S.H., Shoda K., Jo P.D., Kato S. (1979), Active Thermo-Atmosphere Combustion (ATAC) - A new combustion process for internal combustion engines, SAE Technical Papers, 790501, 1-12.

92. Papson A., Creutzig F., Schipper L. (2010), Compressed air vehicles: Drive-cycle analysis of vehicle performance, environmental impacts, and economic costs, Transportation Research Record, Vol. 2191, 67-74.

93. Pavlovic J., Marotta A., Ciuffo B. (2016), CO2 emissions and energy demands of vehicles tested under the NEDC and the new WLTP type approval test procedures, Applied Energy, 177, 661-670.

94. Pesaran A. (2001), Battery Thermal Management in EVs and HEVs : Issues and Solutions, Advanced Automotive Battery Conference, Vol. 10, 1-10.

95. Puškár M., Jahnátek A., Kádárová J., Šoltésová M., Kovanič L'., Krivosudská J. (2019), Environmental study focused on the suitability of vehicle certifications using the new European driving cycle (NEDC) with regard to the affair "dieselgate" and the risks of NO x emissions in urban destinations, Air Quality, Atmosphere and Health, Vol. 12, No. 2, 251-257.

96. Radhakrishna L., Gopikrishna N. (2017), Prefabricating and testing of air driven engine, International Journal of Mechanical Engineering and Technology, Vol. 8, 238-251.

97. Raslavičius L., Azzopardi B., Keršys A., Starevičius M., Bazaras Ž., Makaras R. (2015), Electric vehicles challenges and opportunities: Lithuanian review, Renewable and Sustainable Energy Reviews, Vol. 42, 786-800.

98. Raslavičius L., Keršys A., Makaras R. (2017), Management of hybrid powertrain dynamics and energy consumption for 2WD, 4WD, and HMMWV vehicles, Renewable and Sustainable Energy Reviews, Vol. 68, 380-396.

99. Reitz R.D., Duraisamy G. (2015), Review of high efficiency and clean reactivity controlled compression ignition (RCCl) combustion in internal combustion engines, Progress in Energy and Combustion Science, Vol. 46, 12-71. 
100. Robertson D., Prucka R. (2019), A Review of Spark-Assisted Compression Ignition (SACl) Research in the Context of Realizing Production Control Strategies, SAE Technical Papers, 2019-240027, 1-18.

101. Saiteja P., Ashok B. (2021), A critical insight review on homogeneous charge compression ignition engine characteristics powered by biofuels, Fuel, Vol. 285, 1-34.

102. Santos H., Costa M. (2008), Evaluation of the conversion efficiency of ceramic and metallic three way catalytic converters, Energy Conversion and Management, Vol. 49, 291-300.

103. Sen B., Onat N.C., Kucukvar M., Tatari O. (2019), Material footprint of electric vehicles: A multiregional life cycle assessment, Journal of Cleaner Production, Vol. 209, 1033-1043.

104. Sergaliyev A.S., Khajiyeva L.A. (2017), Experimental Research and Mathematical Modeling of Scroll Machine in Air Motor Mode, Advances in Mechanism Design II, 145-151.

105. Shi Y., Li F., Cai M., Yu Q. (2016), Literature review: Present state and future trends of air-powered vehicles, Journal of Renewable and Sustainable Energy, Vol. 8.

106. Shuai S., Ma X., Li Y., Qi Y., Xu H. (2018), Recent Progress in Automotive Gasoline Direct Injection Engine Technology, Automotive Innovation, Vol. 1, 95-113.

107. Sileghem L., Bosteels D., May J., Favre C., Verhelst S. (2014), Analysis of vehicle emission measurements on the new WLTC, the NEDC and the CADC, Transportation Research Part D: Transport and Environment, Vol. 32, 70-85

108. Szoka W., Szpica D. (2012), Adaptation of classic combustion engines to compressed air supply, Acta Mechanica et Automatica, Vol. 6, 68-73.

109. Szpica D. (2019), Coefficient of Engine Flexibility as a Basis for the Assessment of Vehicle Tractive Performance, Chinese Journal of Mechanical Engineering (English Edition), Vol. 32, 1-9.

110. Szpica D., Korbut M. (2019), Modelling Methodology of Piston Pneumatic Air Engine Operation, Acta Mechanica et Automatica, Vol. 13, 271-278.

111. Szpica D., Korbut M. (2020), Model assessment of inlet timing system impact on cylinder indicated pressure course of piston pneumatic engine, Engineering for Rural Development, Vol. 19, 711-720.

112. Szpica D., Piwnik J., Sidorowicz M. (2014), The motion storage characteristics as the indicator of stability of internal combustion engine - receiver cooperation, Mechanika, Vol. 20, No. 1, 108-112.

113. Thipse S.S. (2008), Compressed air car, Tech Monitor, 6, 33-37.

114. Thiruvengadam A., Besch M., Padmanaban V., Pradhan S., Demirgok B. (2018), Natural gas vehicles in heavy-duty transportation - A review, Energy Policy, Vol. 122, 253-259.

115. Usman M., Farooq M., Naqvi M., Saleem M.W., Hussain J., Naqvi S.R., Jahangir S., Jazim Usama H.M., Idrees S., Anukam A. (2020), Use of gasoline, LPG and LPG-HHO blend in SI engine: A comparative performance for emission control and sustainable environment, Processes, Vol. 8, No. 74, 1-15.

116. Varella R., Duarte G., Baptista P., Sousa L., Villafuerte P. (2017), Comparison of Data Analysis Methods for European Real Driving Emissions Regulation, SAE Technical Papers, 2017-010997, 1-14.

117. Wagner W.C. (1975), US4124978A Compressed air engine.

118. Wang J., Lu K., Ma L., Wang J., Dooner M., Miao S., Li J., Wang D. (2017), Overview of compressed air energy storage and technology development, Energies, Vol. 10, 1-22.

119. Wang Y.W., You J.J., Sung C.K., Huang C.Y. (2014), The applications of piston type compressed air engines on motor vehicles, Procedia Engineering, Vol. 79, 61-65.

120. Wang Z., He X., Wang J.X., Shuai S., Xu F., Yang D. (2010), Combustion visualization and experimental study on spark induced compression ignition $(\mathrm{SICl})$ in gasoline $\mathrm{HCCl}$ engines, Energy Conversion and Management, Vol. 51, No. 5, 908-917.
121. Warguła Ł., Kukla M. (2020), Determination of maximum torque during carpentry waste comminution, Wood Research, Vol. 65, 771-784.

122. Wasbari F., Bakar R.A., Gan L.M., Tahir M.M., Yusof A.A (2017), A review of compressed-air hybrid technology in vehicle system, Renewable and Sustainable Energy Reviews, Vol. 67, 935-953.

123. Weaver C.S. (1989), Natural gas vehicles - A review of the state of the art, SAE Technical Papers, 892133, 1-24.

124. Wittig K. (1925), US1726462A Compressed-air engine

125. Wu W., Wang S., Wu W., Chen K., Hong S., Lai Y. (2019), A critical review of battery thermal performance and liquid based battery thermal management, Energy Conversion and Management, Vol. 182, 262-281.

126. Xia W., Zheng Y., He X., Yang D., Shao H., Remias J., Roos J., Wang Y. (2017), Catalyzed Gasoline Particulate Filter (GPF) Performance: Effect of Driving Cycle, Fuel, Catalyst Coating, SAE Technical Papers, 2017-01-2366, 1-9.

127. Xingcai L., Libin J., Junjun M., Chen H., Zhen H. (2008), Effects of an In-Cylinder Active Thermo-Atmosphere Environment on Diesel Engine Combustion Characteristics and Emissions, Energy Fuels, Vol. 22, No. 5, 2991-2996.

128. Yang J., Roth P., Durbin T.D., Johnson K.C., Cocker D.R., AsaAwuku A., Brezny R., Geller M., Karavalakis G. (2018), Gasoline Particulate Filters as an Effective Tool to Reduce Particulate and Polycyclic Aromatic Hydrocarbon Emissions from Gasoline Direct Injection (GDI) Vehicles: A Case Study with Two GDI Vehicles, Environmental Science and Technology, 52(5), 3275-3284.

129. Yang Q.C., Zhao Y.Y., Li L.S., Qian Z.G. (2013), Investigation on working characteristics of micro compressed air energy storage system, Institution of Mechanical Engineers - 8th International Conference on Compressors and Their Systems, 151-159.

130. Yeh S. (2007), An empirical analysis on the adoption of alternative fuel vehicles: The case of natural gas vehicles, Energy Policy, Vol. 35, No. 11, 5865-5875.

131. Zhang C., Yan B., Wieberdink J., Li P.Y., Van De Ven J.D., Loth E., Simon T.W. (2014), Thermal analysis of a compressor for application to Compressed Air Energy Storage, Applied Thermal Engineering, Vol. 73, No. 2, 1402-1411.

132. Zhao C., Zhang B., Zheng Y., Huang S., Yan T., Liu X. (2020) Hybrid Battery Thermal Management System in Electrical Vehicles: A Review, Energies, Vol. 13, 1-18.

133. Zhou Q., Du D., Lu C., He Q., Liu W. (2019), A review of thermal energy storage in compressed air energy storage system, Energy. Vol. 188.

134. Zhou, S. Walker P., Zhang N. (2020), Parametric design and regenerative braking control of a parallel hydraulic hybrid vehicle, Mechanism and Machine Theory, Vol. 146, 1-15.

135. Zwierzchowski J. (2017), Design type air engine Di Pietro, EPJ Web of Conferences, Vol. 143, 1-6.

This research was financed through subsidy of the Ministry of Science and Higher Education of Poland for the discipline of mechanical engineering at the Faculty of Mechanical Engineering Bialystok University of Technology WZ/WM-IIM/4/2020.

Michał Korbut: iD https://orcid.org/0000-0001-7515-3800

Dariusz Szpica: (ID https://orcid.org/0000-0002-7813-8291 